\title{
Implementation of Management Based on Islamic Spiritual Entrepreneurship for the Success of Madrasah Management
}

\author{
Muhammad Sadri1 ${ }^{*}$, Faisar Ananda ${ }^{1}$, Saparuddin Siregar ${ }^{1}$
}

\section{ABSTRACT}

This study discusses how the implementation of Islamic Spiritual Entrepreneurshipbased madrasa management in achieving the success of madrasa management in Langkat. The form of madrasa management based on Islamic Spiritual Entrepreneurship management which is analyzed through the form of the process of implementing education, funding, marketing / promotion, human resource management and the environment which is carried out based on the concept of Islamic Spiritual Entrepreneurship (honesty, gratitude, Islamic values, blessings of Allah SWT and the concept of worship. to Allah SWT). The location of this research was conducted at 60 madrasa in Langkat by taking sambel 300 respondents consisting of leaders, teachers, education staff and management. The research is field research using naturalistic qualitative techniques. The data were collected using interview, observation and documentation methods. The data were analyzed and verified and then concluded that it was inductive. The results of the study prove that 1) madrasas in Langkat have not maximally implemented Islamic Spiritual Entrepreneurship on school management because there is no strong commitment to all management to apply the concept 2) Not all Islamic Spiritual Entrepreneurship management criteria are applied in the management of madrasa which are religious-based schools of Islam 3) Collaboration is needed from TOP Management to students in applying the concept of Islamic Spiritual Entrepreneurship in school management so as to achieve competitive advantage and management sustainability until the future.
\end{abstract}

Keywords: madrasa, management, Islamic, Spiritual, Entrepreneurship

DOI : https://doi.org/10.30596/ijbe.v2i1.5716

JEL Classification : M00, L26

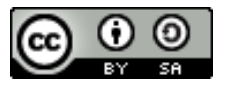

Published by International Journal of Business Economics (IJBE), Indonesia | Copyright (C)2020 by the Author(s) | This is an open access article distributed under the Creative Commons Attribution License http://creativecommons.org/licenses/by/4.0), which permitsunrestricted use, distribution, and reproduction in any medium, provided the original work is properly cited.

Cite this article as:

Sadri, M., Ananda, F., \& Siregar, S. (2020). Implementation of Management Based on Islamic Spiritual Entrepreneurship for the Success of Madrasah Management. International Journal of Business Economics (IJBE), 2(1), 29-38.

${ }^{1}$ Faculty of Economics and Business of Islamic, UIN Sumatera Utara

Jl. IAIN No.1, Gaharu, Kec. Medan Tim., Kota Medan, Sumatera Utara 20235,

Indonesia

*Corresponding Author: soedrytheone@gmail.com 


\section{International Journal of Business Economics (IJBE)}

Vol, 2 Issue 1, pp 29-38, Sept 2020

http://jurnal.umsu.ac.id/index.php/ijbe

eISSN 2686-472X

\section{INTRODUCTION}

There are still many madrasas in Indonesia that have low performance. Madrasa is the final choice or even not included in the community's choice of places of education because of the assumption that the quality of madrasa education is still far behind conventional public schools and is considered not adaptive to the times.

The cause of this backwardness and negative stigma is the existence of an unprofessional attitude, an ineffective form of leadership in its implementation, resulting in quality and quantity gaps. (Tafsir 1994) Many madrasas have decreased in quality due to the factors of leaders and staff who do not have good character, unable to act as agents of change and managers of change (Edmond 1979) It is known that there is a significant relationship between the success of an institution with good leadership as part of effective leadership and efforts to increase achievement (Tobroni 2012)

Learning from madrasa in East Java which have an effective form of leadership, with good character for all members of the management organization makes madrasa a superior educational institution. It is proven that this excellence is obtained because of the form of leadership that guides the management of transformational spiritual-based madrasas, namely managing madrasa with spiritual, professional and human values.(Muhammad 2019)

Madrasas in Langkat are the target of this study because of the low level of quality and competitive advantage over general schools. It is known from the author's observations that madrasa still have deficiencies in their management or organizational management. Management is traditional, the curriculum does not keep up with the development of science and technology, its graduates are deemed not able to compete with other graduates, the teaching staff is also considered to be less professional at the level of education(Qomar 2007) This means that madrasas in Langkat have not performed well. There needs to be a clear vision of the madrasa, namely the existence of Islamic character as a Muslim person in various situations and conditions in schools and the general public, a holistic orientation that places spiritual and transcendental values to achieve learning objectives so that it is easy to develop insights and skills in an integrated manner, and is quality oriented, namely educational processes and outcomes.

The management model of Islamic spiritual entrepreneurship is considered the most successful to be applied as a strategy to change the method of managing madrasas in Langkat to have good performance resulting in high quality education and highly competitive graduates. An organization with a spiritually-based culture provides a good impact on being able to adapt to various environmental changes. Not only that, it is also proven that Islamic spiritual values which are used as guidelines for business practice are known not to conflict with the entire process of business management and management implementation, but instead help business success (Fonneland 2012; Vargas-Hernandez 2010) It can be seen from several business and management practices that use Spiritual Islamic values to have a positive impact on entrepreneurs and business people and develop their business to the maximum.

Therefore this research was conducted to examine the management concept of Islamic spiritual entrepreneurship in madrasa management in Langkat Regency and the extent to which this application is practiced in madrasa management to support the successful management of madrasa in Langkat. 


\section{International Journal of Business Economics (IJBE)}

Vol, 2 Issue 1, pp 29-38, Sept 2020

http:/ /jurnal.umsu.ac.id/index.php/ijbe

eISSN 2686-472X

\section{METHODS}

This research was conducted in Langkat by determining the population was 60 madrasa with a sample selection of 300 people with the criteria of madrasa leaders ( 2 people), administrative staff (education staff) ( 2 people), and teachers ( 1 person). There are 5 representatives of each madrasa, so the sample size is 300 people (5x60 madrasa). The sample was selected by purposive sampling technique. Data were collected using interview and observation techniques assisted by a questionnaire. This type of research is qualitative with data collection procedures through the initial study of documentation and observation. Then, the data was reduced to assess and write the most appropriate and important data to answer the problem regarding the implementation of Islamic Spiritual entrepreneurship management in the management of madrasa in Langkat. After that, the data is presented through analysis, interpretation of the results and integration with theory. Finally, a conclusion will be drawn as the final part of the research.

\section{RESULTS AND DISCUSSION}

Observations and interviews were conducted with madrasa managers consisting of leaders, teachers (teaching staff), administrative staff (education personnel) from 60 madrasas in Langkat. It is known that madrasah managers are dominated by $62.33 \%$ of women with a bachelor's level education. The results of the review show that $60 \%$ of madrasa managers do not know the concept of Islamic Spiritual Entrepreneurship, but there are $65 \%$ who state that they think they have not implemented the concept in their work.

The concept of Islamic Spiritual Entrepreneurship Management is built on Islamic values, the concept of worship to Allah SWT, the Blessings of Allah SWT, Behavior of Gratitude and Honest Behavior which is run by the management of madrasah management in Langkat.

Islamic values in the form of siddiq, amanah, tabligh, fathonah get good criteria, meaning that all madrasa managers understand that these values are important in life when working guided by the example of the Prophet Muhammad. The concept of worship to Allah also received a positive response in the good category by all madrasa managers. All management implementers (55\%) understand well that humans belong to Allah, all entrusted by Allah SWT so that everything that is obtained in this world is a responsibility that must be carried out properly as a form of worship to Allah SWT.

Blessings from Allah SWT are also part of the management concept of Islamic Spiritual entrepreneurship which is given positive responses with good criteria. The majority of mandrasah implementers, 55\%, think that working in managing a madrasa as an Islamic religious education institution must avoid dangerous things and are blessed by Allah SWT so that they get inner peace.

Gratitude behavior is part of the management concept of Islamic spiritual entrepreneurship. there is a behavior of gratitude to Allah SWT in the management of madrasah management in Langkat. This grateful behavior also gets a good category from all research respondents who say that they give positive statements is $>50 \%$. Honest behavior is given a positive response so that it is included in the good category by> $60 \%$ of respondents that honesty is an important factor in running madrasa school management considering that madrasas are Islamic-based education. 


\section{International Journal of Business Economics (IJBE)}

Vol, 2 Issue 1, pp 29-38, Sept 2020

http:/ /jurnal.umsu.ac.id/index.php/ijbe

eISSN 2686-472X

\section{Discussion \\ Form of Madrasah Management in Langkat}

The management of madrasa in Langkat still applies the traditional management model, has not been close and adapted to change and there is still an impression that it is far from modernizing. The results of observations and interviews also obtained information from respondents that it is known that generally madrasas do not yet have an effective management model that can direct the curriculum and quality of education that follows the times without having to leave the religious foundation, namely Islam.

Madrasa as Islamic-based schools are still looking for an appropriate management model design that can present an Islamic education model that is able to follow and contribute to commodities and the tendency of globalization in the current industrial era 4.0.(Eriyanto 2019) Madrasahs are known to have traditional management practices that still apply the dominance of seniority which interferes with the development and improvement of the quality of education. The presence of creativity and innovation from young people is seen as a threat and behaviour that does not respect seniors, as a result suggestions and criticism become su'al-adab. Local culture also lowers the notion that madrasa schools are lowquality, unqualified, out-of-date educational institutions that only teach religion, major in the hereafter and are places to accommodate children who have not graduated from public or public schools.

The development of the times is considered to be a challenge or obstacle to the development of the quality of madrasa education, so that madrasa management finds it difficult to manage madrasa to produce educational curricula, as well as the quality of madrasa graduates that are highly competitive. Even though we all know that madrasas exist by offering education based on Islam, and we all know that Islam is not in conflict with the times or any modernization at any time. Even madrassas as educational institutions that are concerned with transforming Islamic values as a counter to cultural imperialism which is invading the eastern world (Muslim society), especially Indonesia.

The madrasa in Langkat also has weaknesses in its management. The weakness of madrasah management is also supported by the attitude of the management, or the madrasah management, which is not professional in its administration, which has an impact on quality and quantity gaps. Madrasas are increasingly deteriorating in quality due to unsuccessful leadership and staff who do not carry out their roles properly (not reflecting good results). It is stated that there is a strong relationship between the success of effective institutions and good leaders, effective leadership because they continue to strive for achievement.(Tobroni 2012)

A good and effective form of leadership has values, beliefs and personal characteristics that are strong, professional, and able to analyze and adapt to the school context. (Leithwood et al. 2010). This form of leadership is very little applied in Indonesia, especially in Langkat. Various studies have shown that educational institutions need a good management strategy, choosing the right management model so that the quality of education can increase successfully. Madrasas in Langkat are included in the category of educational institutions that require proper management of madrasahs so as to improve the quality of education and produce quality graduates who are highly competitive.

The results of observations and interviews found that out of the 60 madrasas that were the objects of research in Langkat still lacked of organizational planning. Madrasas in Langkat are still the last school of choice for parents to send their children to school because they are considered not modern, the curriculum is not up to date because it is dominant only 


\section{International Journal of Business Economics (IJBE)}

Vol, 2 Issue 1, pp 29-38, Sept 2020

http://jurnal.umsu.ac.id/index.php/ijbe

eISSN 2686-472X

about religion (30\% general knowledge and $70 \%$ religious knowledge) compared to the conventional school curriculum (30\% religion and $70 \%$ of general knowledge) weakens the competitiveness of madrasahs against general schools. In addition, graduates will be deemed unable to compete with general school graduates to enter favorite or public schools. More than that, teaching staff or teachers are considered less professional in their education level (Qomar 2008) The striking difference between madrasa and public schools can be seen in addition to the tradition of the learning process as well as alumni access to universities and the world of work.

Madrasahs in Langkat have not performed well because they have not been able to manage the institution properly with good leadership. Madrasahs do not yet have proper and independent planning, implementation, supervision and financing, so they have not succeeded in becoming effective educational institutions (Mulyasa 2009) There needs to be a clear vision of madrasas, namely the existence of Islamic character as a Muslim person in various situations and conditions both in schools and in the general public, a holistic orientation that places spiritual and transcendental values to achieve learning goals so that it is easy to develop insights and skills in an integrated manner, and is oriented towards quality, namely the process and results of education. So madrassas must have a management system that is appropriate and strategic in order to be able to continue to meet or match the needs of society, namely providing quality education, producing high quality graduates not only in the field of Islam but also becoming graduates who are literate and able to adapt to scientific advances. and technology, has produced results that are beneficial to the progress of the nation, especially Muslims in Indonesia

\section{Application of Management Based on Islamic Spiritual Entrepreneurship in Achieving Successful Management of Madrasa In Langkat}

Madrasa in Langkat can study with madrasas in East Java that have succeeded in producing superior academic and non-academic achievements. Madrasas in East Java are able to build good forms of leadership in managing schools. Forms of leadership and management practices based on spiritual, professional and humanity. Madrasahs are managed with a form of leadership and management practices based on transformational spirituality, which are managed by applying spiritual, professional and human values(Muhammad 2019) Spiritual values and strong religious commitment are articulated in the processes and procedures for managing superior madrasas, in the form of optimism, confidence, sincerity, tawakkal, humility and the four characteristics of the Prophet, namely honesty, trustworthiness, tabligh and fathonah. Other values that underlie the work pattern of Madrasa management are sincerity and tawakkal. Tawakkal means having an attitude that places trust in Allah above belief in anything and anyone. Running madrasa coupled with innovation is done sincerely and tawakkal, because it is done wholeheartedly and submits to Allah SWT.

The principle of leadership which is al-amr bi al-Ma'ruf wa al-Nahyu an al-Munkar is highly emphasized by Allah, because it gives birth to changes that bring good and benefit to the people. The success of madrasa can reflect the spiritual values that school leaders believe in everything that madrasa must achieve. These values greatly influence all the leadership practices of madrasah principals in making excellent madrasas, their leadership processes and procedures. This is in line with the findings of the literature on moralist leadership, that values are the main thing in all leadership practices of madrasah leaders. The principal of 


\section{International Journal of Business Economics (IJBE)}

Vol, 2 Issue 1, pp 29-38, Sept 2020

http://jurnal.umsu.ac.id/index.php/ijbe

eISSN 2686-472X

the moralist madrasah brings the institution towards the vision or goal with the full conviction that they stand on moral and educational values.

The management model based on spiritual entrepreneurship is considered as the most appropriate strategic concept to change madrash management methods for the better and able to face and adapt to the challenges of globalization. This management concept is considered to be a strategy by madrasa managers in Langkat so that they can adjust to the advances in science and technology they are facing. The results of the literature study show that several studies have proven that many organizations and companies have succeeded in developing their businesses because they apply the values of Islamic Spiritual Entrepreneurship. It is stated that the behavior of entrepreneurs who apply Islamic Spiritual values in running their business is able to improve their business, even it is sustainable and does not conflict with modernization and is not anti-progress (Kayed and Hassan 2010). It is the same as what Fonneland proposes, that a business culture that applies a spiritual-based model that directs entrepreneurs and management managers who use spiritual values such as self-development, holism and other spiritual values have a positive impact and then their efforts are able to adapt to various type of environment and local culture of the community (Fonneland 2012). Not only that, it is known that Vargas et al. applying Spiritual Islamic values in business practice does not seem to contradict all business management and business management practices and instead helps entrepreneurs succeed(Vargas-Hernandez 2010).

Madrasa in Langkat is known from the results of identification of observations and interviews with respondents, namely that the application of Islamic values exemplified by the Prophet by school managers is not fully carried out at work. The results of the descriptive analysis of the respondents show that it is true that more than 50\% of the research respondents do not know the concept of Islamic sharia-based management. And stated that they do not apply Islamic values in carrying out their duties in managing madrasa management. But this does not give an idea that the management and employees are not practicing Islamic law, it's just that it is more dominant in personal life and less reflects behaviour at work.

Islamic values that reflect the behaviour of madrasa management in Langkat Regency cannot be fully applied in work. in fulfilling their responsibilities when carrying out their duties to manage madrasa management. The impact can be seen from the slow progress of Madrasa's development and does not fulfils the people's desire for the need for quality educational institutions. These Islamic values are not optimal in their implementation in carrying out the management functions of madrasa so that the development of madrasas tends to be slow and unsustainable. only $40 \%$ stated that they knew the concept of Islamic Spiritual Entrepreneurship, while the rest, 60\% said they did not know it. In fact, it is also known from the number who know or know the concept of Islamic Spiritual Entrepreneurship, it turns out that only $35 \%$ stated that they carry out all their duties in managing madrasah management. Even though it is known that Islamic values in entrepreneurial activities carried out by business management players based on Islamic spiritual entrepreneurship help them get halal income and have a great opportunity for running a business to contribute to a better community life. Even Islamic values are not in conflict with modernization and are not against progress and even help business development for the better (Kayed and Hasan 2010). Some quality management concepts that can be applied are quality pillars based on madrasa beliefs such as trust, cooperation and leadership. which reflects Islamic values. The organization will change the work pattern based on Islamic spiritual entrepreneurship which contains Islamic values in it. All 


\section{International Journal of Business Economics (IJBE)}

Vol, 2 Issue 1, pp 29-38, Sept 2020

http:/ /jurnal.umsu.ac.id/index.php/ijbe

eISSN 2686-472X

employees must be service quality oriented, honest, trustworthy, disciplined, patient, sincere and sincerely love their work as a mandate and hope for the pleasure and blessings of Allah SWT (Rasi'in 2016)

Not only employees, teachers must also reflect the behaviours of believers and Muslims, have good and broad scientific insight, are creative, dynamic, innovative, honest, have noble morals, are highly disciplined and sincere in all their work because they contain the concept of worship to Allah in their job. Islamic values as part of the principles of spiritual entrepreneurship are a promising plus if applied by all madrasa management. Management is more independent and applies honest, trustworthy, professional behaviour, has high credibility and is competitive so that it is considered capable of supporting the sustainability of madrasa educational institutions because of an assessment that Islamic Spiritual values will not be contradicting with modernity or the times.

A Muslim must realize the importance of spiritual values that are applied in the business world, where these values are based on religious teachings which are our responsibility to God, namely Allah SWT. The management of this madrasa, starting from owners, teachers, employees and management, must be aware that every activity we do or work that is done is the interference of the Khaliq so that we must uphold religious values and implement them in our behaviour and become a form of our worship to Allah SWT. Making the spirit of Islamic religious values a guide for running a business and becoming part of the management process of madrasa management. There were $56.7 \%$ who agreed and $30.7 \%$ who strongly agreed. But there is also a group of respondents who disagree, namely less than 5\% $(2.7 \%)$ because for them the spirit of Islamic religious values cannot be fully applied, because it can be out of date so that madrasas need to modify Islamic principles with changes and developments. era. This group forgets that the principles of the Islamic Religion will not fade and can adapt to modernization and the times (Kayed and Hassan 2010; Sunita and Anthuvan 2015).

The concept of management based on Islamic Spiritual Entrepreneurship is also reflected in the management of madrasa who will feel inner calm, ease of affairs, the feeling of Allah blessing all his work, having effective and useful assets and without realizing it, Allah SWT provides protection from dangerous things. This means that blessings from Allah SWT are part of the factors that support the implementation of good madrasa management, supporting the success of this educational institution in a sustainable manner to provide quality and beneficial education for the community. This blessing is an important factor in achieving business continuity based on Sharia principles. Madrasa education institutions as Islamic religious-based educational institutions must certainly be in the corridor of Islamic law (Handayani 2007). This urgency covers the fields of educational management ranging from curriculum management, personnel management, student management, financial management and environmental management.

Respondents stated that respondents tried to work as well as possible. There is always an effort to provide the best in service and fulfil responsibilities to the institution / management and also in providing services to madrasa's students. The behaviour of gratitude and gratitude within the institution will be able to increase the productivity and performance of all employees of management as well as the performance of madrasa. This gratitude is also part of the management concept of management based on Islamic Spiritual Entrepreneurship values that prioritizes goodness at work. The behavioural factor of gratitude is an insignificant factor in the management of madrasa management based on Islamic values because the indication of gratitude is difficult to assess in real terms. Gratitude 


\section{International Journal of Business Economics (IJBE)}

Vol, 2 Issue 1, pp 29-38, Sept 2020

http:/ /jurnal.umsu.ac.id/index.php/ijbe

eISSN 2686-472X

is part of motivation, so that people or employees do not always have positive motivation at work. Generally, the challenges come from the environment, colleagues and superiors who cannot motivate employees to work. In the interview session when distributing the questionnaire, there were several statements from employees stating that they sometimes find it difficult to find motivation to work. Some of them are leaders who are not able to know employees and their employees' needs appropriately, leaders are also considered unable to motivate employees according to the needs and expectations of their employees, lack of supervision causes employees to lack discipline in work, there are employees who are lazy to work so that they are not productive. This certainly has an impact on the performance of the institution or the performance of the madrasa. The role of the leader as director and controller must show a form of warmth, positive values when managing madrasa management. These values are self-confidence, which will make employees feel optimistic about what is done and the results to be achieved. This value is also related to intelligence, skills in leadership that support the values of truth, honesty, integrity, credibility, wisdom, compassion which helps to shape one's morals and morals(Al Banjar 2008)

The honesty factor is the most significant factor in supporting the management of madrasa management based on Islamic entrepreneurship values in Langkat. The principle of honesty contains several determining factors, namely the existence of honest behaviour in the form of honest words and actions and does not take the rights of others. And the most dominant factor in determining honest behaviour in order to support the successful implementation of madrasah management is that the management must be committed. Have a match between words and deeds. The concept of conventional management is also in line with Islamic management, where the professional competence of management executives is to have a code of ethics, trust, honesty and healthy competition. The existence of honesty has also proven to be one of the competencies or attitudes needed in implementing institutional management and including madrasah management requires that competence. But another obstacle that is felt to the application of this honesty in management is that management leaders and supervisors can also not prioritize honesty in their work, be dishonest and not transparent in managing management. Management does not fully assist employees in running the institution / organization.

Madrasa according to its definition is a school or educational institution that provides education for students to get the values of faith and devotion, caring character, ethics, noble character, honest and integrated. This means that madrasa to create targeted graduate competencies must carry out management that prioritizes high integrity. And this integrity is part of honesty which is part of Sharia-based management. In general, the internalization of character values in the madrasa management process has been implemented even though it is not optimal. The implementation of character education is still running smoothly without any implementation instructions that can be used as a reference for the implementation of character education. However, the commitment of teachers, employees, and students is quite good in obeying and carrying out the prevailing rules and regulations. Activities in the madrasa environment, both in the learning process and outside of learning are carried out by prioritizing the development of noble character and moral values. In addition, the role of the head of the madrasa as top manager can function properly, by constantly controlling and coaching teachers, employees and students. In addition to through discipline, the head of madrasah makes modelling as a strategic means of character building for students. Madrasa 


\section{International Journal of Business Economics (IJBE)}

Vol, 2 Issue 1, pp 29-38, Sept 2020

http:/ /jurnal.umsu.ac.id/index.php/ijbe

eISSN 2686-472X

must build quality as an educational institutions that have advantages that are believed are of course based on Islamic sharia values.

A quality madrasa can certainly create a quality education. This quality is not only seen from the quality of the graduates, but also from the strategies in improving the quality of these graduates. This quality is related to the service process provided by all madrasa education management implementers for the community, both to students as the main customers who receive educational services, parents and the community as users of educational outcomes. Efforts to produce quality start from providing educational services that direct all supporting resources ranging from material resources to non-material resources. All of these efforts must be carried out with the four principles that are the pillars of the implementation of Islamic Education Institutions to achieve the natural blessings of doing business. There are principles of faith, principles of trust, principles of balance, and principles of Ihsan. (Huda 2016).

\section{Implications}

This research is a recommendation for madrasa managers to make the concept of Islamic Spiritual entrepreneurship the basis for madrasa management because the majority of madrasas in Langkat still apply traditional and conventional management concepts. A large number of research literature proves that the concept of spiritual entrepreneurship supports organizational success and sustainability. The next research can be focused on examining the effect of the Islamic Spiritual Entrepreneurship management concept on improving the quality of madrasa management.

\section{CONCLUSION}

Islamic Spiritual entrepreneurship management is a potential strategy to support the successful achievement of madrasa management to compete in the development of globalization. The existence of Islamic values, honesty, grateful behavior, the concept of worship to Allah and the blessings of Allah SWT are recognized as sharia values that apply universally to build positive character and build effective leadership, become part of reliable organizational management for sustainability and competitive advantage of an organization, especially madrasas in Langkat. It is known that all managers understand the concept, but they believe that not all Islamic spiritual entrepreneurship management concept instruments can be fully implemented in their work. They realize that the management concept of Islamic spiritual entrepreneurship is the right concept and promises the success and sustainability of the organization, but the leadership must continue to take a holistic approach, coaching and supervising and providing an example of madrasah management so that it will be maximally successful in achieving madrasa management to achieve competitive advantage and produce quality the best education for the people in Langkat.

\section{REFERENCES}

Al Banjar, Rachmat Ramadhan. 2008. Prophetic Leadership: Membentuk Kepribadian Para Pemimpin Berbasis Spritualitas Dan Menumbuhkan Potensi Dan Karisma Kenabian Dalam Diri Para Pemimpin. Yogayakarta: DIVA Press.

Edmond, R. 1979. Effective Schools for the Urban Poor. Educational Leadership. Eriyanto. 2019. "Pengelolaan Madrasah Yang Efektif: Menjawab Tantangan Pendidikan Islam Di Era Industri." Pendidikan Islam Indonesia 4(1): 74-88.

Fonneland, Trude. 2012. "Spiritual Entrepreneurship in a Northern Landscape: Spirituality, 


\section{International Journal of Business Economics (IJBE)}

Vol, 2 Issue 1, pp 29-38, Sept 2020

http://jurnal.umsu.ac.id/index.php/ijbe

eISSN 2686-472X

Tourism and Politics." Temenos 48(2).

Handayani, Niken. 2007. "Modal Sosial Dan Keberlangsungan Usaha.” Universitas Sebelas Maret.

Huda, Choirul. 2016. "Model Pengelolaan Bisnis Syari'ah: Studi Kasus Lembaga Pengembangan Usaha Yayasan Badan Wakaf Sultan Agung Semarang." Walisongo: Jurnal Penelitian Sosial Keagamaan 24(1).

Kayed, and Hasan. 2010. "Islamic Entrepreneurship: A Case Study Of Saudi Arabia." Journal of Developmental Entrepreneurship 15(4): 379-413.

Kayed, and Hassan. 2010. "Islamic Entrepreneurship: A Case Study Of Saudi Arabia." Journal of Development Entrepreneurship 15(4): 379-413.

Leithwood, Kenneth A., Karen Seashore Louis, Stephen Anderson, and Kyla Wahlstrom. 2010. "How Leadership Influences Student Learning." http://www.wallacefoundation.org. (June 12, 2020).

Muhammad, Walid. 2019. "Nilai-Nilai Spiritual, Profesional, Dan Humanis Pada Kepemimpinan Kepala Madrasah Unggulan Di Malang." Pendidikan Agama Islam $5(2)$.

Mulyasa. 2009. Manajemen Berbasis Madrasah: Konsep, Strategi, Dan Implementasi. Bandung: Remaja Rosdakarya.

Qomar, Mujamil. 2007. Manajemen Pendidikan Islam.

_. 2008. Manajemen Pendidikan Islam. Jakarta: Erlangga.

Rasi'in. 2016. "Menakar Standar Madrasah Bermutu.” Kordinat VX(1): 75-88.

Sunita, R, and VL Anthuvan. 2015. "Rohani Intelijen Dan Wirausaha Sukses Di Bisnis Keluarga." Sebuah Inquiry 17(6).

Tafsir, Ahmad. 1994. Ilmu Pendidikan Dalam Prespektif Islam. Bandung: Remaja Rosda Karya.

Tobroni. 2012. "Manajemen Dan Kepemimpinan Pendidikan Islam : Mencari Format Baru Manajemen Yang Efektif Di Era Globalisasi." Nadwa 6(1): 1-26.

Vargas-Hernandez. 2010. "An Exploration of the Affects of Islamic Culture on Entrepreneurial Behaviors in Muslim Countries." Asian Social Science 6(5): 120-27. 